Research Article

\title{
Cost Estimation of Structural Components of a Building by considering the Seismic Load on Different Regions
}

\author{
Mubarak Mubarak (D), ${ }^{1}$ Abdullah Abdullah, ${ }^{2}$ Azmeri Azmeri, ${ }^{2}$ and Yulia Hayati ${ }^{2}$ \\ ${ }^{1}$ Engineering Doctoral Study Program, Universitas Syiah Kuala, Banda Aceh 23111, Indonesia \\ ${ }^{2}$ Department of Civil Engineering, Universitas Syiah Kuala, Banda Aceh 23111, Indonesia \\ Correspondence should be addressed to Mubarak Mubarak; mubarak@unsyiah.ac.id
}

Received 13 August 2019; Revised 19 November 2019; Accepted 21 November 2019; Published 18 December 2019

Academic Editor: Francesco Colangelo

Copyright (c) 2019 Mubarak Mubarak et al. This is an open access article distributed under the Creative Commons Attribution License, which permits unrestricted use, distribution, and reproduction in any medium, provided the original work is properly cited.

\begin{abstract}
Seismic loads should be considered in the cost estimation process as a consequence of changes in structural dimensions. Seismic loads received by buildings vary from one region to another, which are used as a basis for dimensioning structural components. This paper aims to investigate the potential cost changes of the reinforced concrete (RC) beam and column elements as an implication of variations in seismic load received by a building constructed in different seismic areas. This study was applied to a prototype of the two-story building. The structure analysis performed with dynamic analysis by varying seismic design categories based on eight seismic zones in the observed area. The utilization of a building prototype was applied to three indices of seismic importance factor to represent the building occupancy category. The results of the study explaining the increase in the total cost of the two RC elements are $0.68 \%, 1.70 \%$, and $1.54 \%$, respectively, for the seismic importance factor indices of $1.00,1.25$, and 1.50 . The variations of the costs due to the factor of seismic load and building occupancy categories indicate that both factors need to be considered in the cost estimation process of buildings.
\end{abstract}

\section{Introduction}

The earthquake risk consideration as one of the critical loads is required in the design process of a building to accommodate its potential occurrence. When a building failed to withstand seismic loads, it causes damage in various levels, both minor and severe damages, or even collapse [1-3]. Indonesia, a country with various seismic potentials, especially in Aceh Province, has seen several high-intensity earthquakes occur in the last 15 years [4-6]. The magnitude of the potential seismic load that may be received by a building is determined by some interrelated factors. Seismicity around the construction site can determine earthquake disturbances; characteristics of soil movements, [7] such as amplitude, duration, and predominant period; and structural dynamic response characteristics, such as natural periods, attenuation factors, and ductility factors $[8,9]$. Building dimensions in some locations may be affected differently by seismic loads. The building's flexibility plays one of the leading roles during an earthquake. The high-towide ratio of a building defines its flexibility.

Understanding the seismic potential is essential during the structure design process of a building [10], especially in buildings that are constructed at locations with a high level of earthquake vulnerability $[11,12]$. Regarding the type of structure material, studies have been carried out related to reinforced concrete structures [13, 14], steel structures $[15,16]$, and composite materials $[17,18]$. For the aspect of structural components, some studies were conducted focusing on frame structures [19-23], beam and column structures [24-27], and other structural components, namely, slab [28] and wall [29, 30]. Earthquake potential has also been assessed by examining aspects of risk to structural elements [31], regularity shapes of building [32], building utilization [33,34], potential seismic hazards $[35,36]$, and cost of damages [37-39]. These considerations are vital to ensure appropriate design as well as cost efficiency against earthquake risks [40]. 
The structure is designed not only to meet the requirements of the building safety aspect but also mandatory to consider the economic aspects. The costs required for the structural components of a building need to be estimated by considering the earthquake potential [41-43]. This consideration is intended so that the dimensions of the designed structure effectively withstand all loads and, at the same time, efficient on costs. The total cost of structural components for various potential seismic loads should be estimated by simulating the loads from some seismic design categories. This paper analyzes the total cost of RC structure components affected by seismic loads by considering the seismic design categories and the utilization of building as indicated by seismic importance factors.

\section{Methods}

2.1. The Building Prototype. The building prototype studied was a two-story building with an area of $440 \mathrm{~m}^{2}$ per floor and a height of 4 meters per floor level, as described in Figure 1. The structural components were focused on analyzing the construction of reinforced concrete (RC). The prototype design will be simulated using software for the analysis and structural design system by applying seismic design categories and importance factors to the observed locations within Aceh Province, Indonesia.

2.2. Standard References for Analysis. The dimensions of structure components, and in particular the structure of reinforced concrete beams and columns, are analyzed based on the Indonesian National Standard (which is abbreviated as SNI in Indonesian) as follows:

(1) SNI 1726:2012, the earthquake resistance planning procedures for the structure of buildings and nonbuildings [44]

(2) SNI 1727:2013, the minimum loads for building and other structures design [45]

(3) SNI 2847:2013, the concrete structural requirements for buildings [46]

2.3. Seismic Loads Analysis. The variation of seismic loads in the structure analysis process is determined according to the seismic design category (SDC) and the risk category for all forms of building occupation as referring to SNI 1726: 2012 [44]. SDC reflects the possibility of suffering from earthquake shocks of various intensities to determine the level of seismic resistance required for the new buildings. SDCs take into consideration the type of soil at the site. The analysis considered the implementation of normal Site Class D soils, which are the most commonly found. The SDC for the observed area was differentiated according to the region called "seismic zones," as described in Figure 2.

Zoning classification is determined by seismic acceleration spectral on risk-targeted maximum consider earthquake $\left(\mathrm{MCE}_{\mathrm{R}}\right)$ for short periods $\left(S_{\mathrm{S}}\right)$ and one second $\left(S_{1}\right)$. These values are measured in gravity $(g)$ and obtained from the web-based application provided by the Settlement
Research and Development Centre of the Ministry of Public Works. The application provides values of the spectral parameter based on geographic position coordinates (latitude and longitude) of cities observed, as shown in Table 1.

Seismic load variations are also determined by the importance factors $\left(I_{\mathrm{e}}\right)$ to represent risk categories for all forms of building occupations. The risk category identifies substantial consequences to human life in case of damage or failure caused by exceeded seismic loads. The structure analysis applied four risk categories, namely, risk categories I, II, III, and IV. The factors are distinguished by the index of 1.0 (for risk category I and II), 1.25 (for risk category III), and 1.50 (for risk category IV). The building prototype model was applied in public buildings such as warehouse, shops (for $I_{\mathrm{e}}=1.00$ ), healthcare facilities (for $I_{\mathrm{e}}=1.25$ ), and school buildings (for $I_{\mathrm{e}}=1.50$ ), as referred to SNI 1726: 2012 [44].

\subsection{Reinforced Concrete (RC) Structure Analysis.} Structure analyses were performed based on dynamic analysis using the SAP2000 International v.20.0.0 Ultimate International Academic software. The load's information as inputs was referred to as SNI 1727:2013 [45]. The outputs of the analysis provide the dimension data of the concrete area $\left(A_{\mathrm{C}}\right)$, the reinforcement area $\left(A_{\mathrm{R}}\right)$, and the longitudinal reinforcement ratio $(\mathrm{RL})$. The structure analysis was conducted on RC beams and columns. The RC structures components were designed based on the provisions of SNI 1726:2012 [44]. The materials of structural components were designed to use concrete quality $\left(f^{\prime} \mathrm{c}\right)$ of $25 \mathrm{MPa}$ and reinforcement steel quality $(f y)$ of $400 \mathrm{MPa}$.

Beams are classified as flexural elements that carry inner forces in the form of bending moments and shear forces that functions to channel the moment to the columns. The initial dimension of RC beam height $(h)$ is determined based on the beam length $(L)$, and the width $(w)$ is planned proportionally to the height [46]. In this study, the initial dimensions $(w \times h)$ were $(20 \times 30) \mathrm{cm}^{2}$ for tie beam, $(25 \times 40) \mathrm{cm}^{2}$ for floor beam, and $(20 \times 25)$ $\mathrm{cm}^{2}$ for roof beam. The initial dimensions were applied to Zone 10 as the minimum observed seismic acceleration spectral $\left(S_{\mathrm{S}}=0.691 \mathrm{~g}\right)$ and importance factor of $I_{\mathrm{e}}=1.00$. Changes in dimensions for subsequent zones and importance factor will be adjusted to changes in the seismic load received by the $\mathrm{RC}$ beam. Changes and adjustments to the dimensions of the concrete cross section made for the condition of the reinforcement ratio (RL) have exceeded the maximum tolerable ratio of 0.025 based on SNI 2847: 2013 [46].

Columns are the structural element functioning as the primary load-carrying element of the building and included as specific moment-resisting frame systems. All RC columns were designed in a square shape $(w \times w)$. The initial RC column dimension was $(25 \times 25) \mathrm{cm}^{2}$ applied for the building model in Zone 10, and changes in concrete dimensions for subsequent zones and importance factor $\left(I_{\mathrm{e}}\right)$ were determined by the longitudinal reinforcement ratio $(\mathrm{RL})$. The ratio increased following the increase in the load 


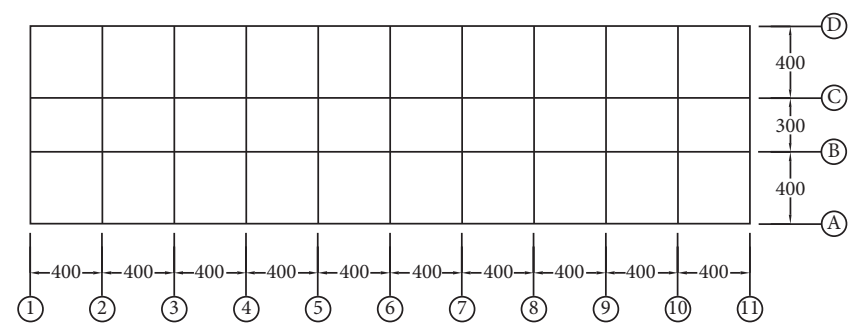

(a)

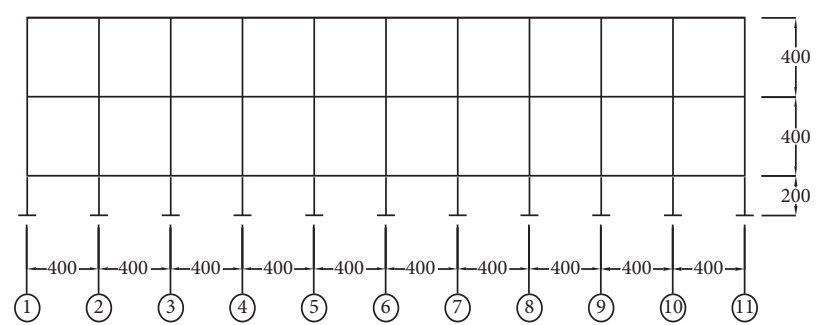

(b)

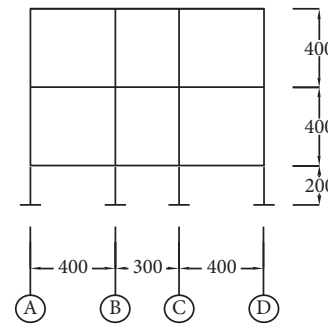

(c)

FIGURE 1: Building structure model: (a) building layout plan; (b) longitudinal section; (c) cross section.

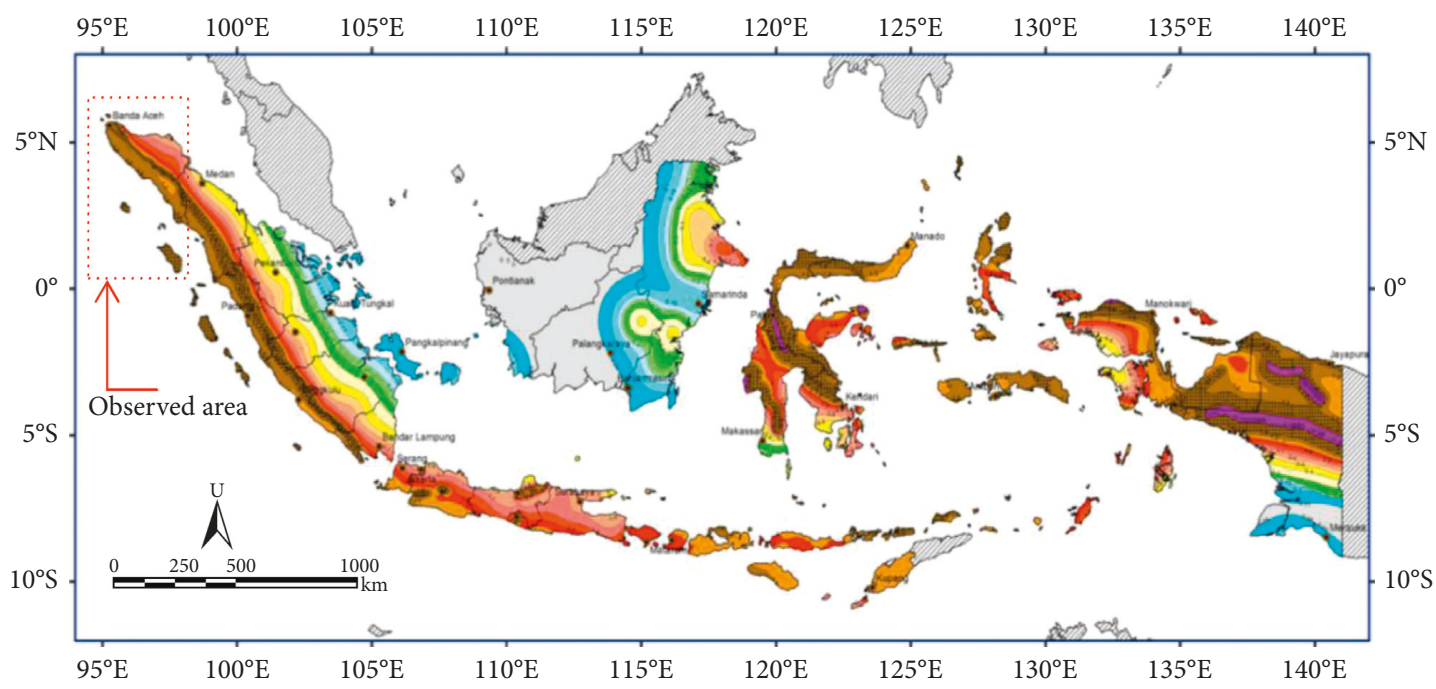

Figure 2: Indonesian seismic map [47].

TABLe 1: Seismic zones and cities observed [47].

\begin{tabular}{lccccc}
\hline $\begin{array}{l}\text { Seismic } \\
\text { zones }\end{array}$ & $S_{\mathrm{S}}$ range & Cities & $S_{\mathrm{S}}$ & $S_{1}$ & Legend \\
\hline 10 & $0.6-0.7 \mathrm{~g}$ & Langsa & $0.691 \mathrm{~g}$ & $0.329 \mathrm{~g}$ & \\
11 & $0.7-0.8 \mathrm{~g}$ & Bireuen & $0.742 \mathrm{~g}$ & $0.366 \mathrm{~g}$ & \\
12 & $0.8-0.9 \mathrm{~g}$ & Sigli & $0.873 \mathrm{~g}$ & $0.427 \mathrm{~g}$ & \\
13 & $0.9-1.0 \mathrm{~g}$ & Meuredu & $0.921 \mathrm{~g}$ & $0.437 \mathrm{~g}$ & \\
14 & $1.0-1.2 \mathrm{~g}$ & Sabang & $1.192 \mathrm{~g}$ & $0.543 \mathrm{~g}$ & \\
15 & $1.2-1.5 \mathrm{~g}$ & Calang & $1.487 \mathrm{~g}$ & $0.600 \mathrm{~g}$ & \\
16 & $1.5-2.0 \mathrm{~g}$ & Kutacane & $1.585 \mathrm{~g}$ & $0.634 \mathrm{~g}$ & \\
19 & $150 \% g$ & Sinabang & $1.500 \mathrm{~g}$ & $0.600 \mathrm{~g}$ & \\
\hline
\end{tabular}

received by RC columns, and when it has exceeded the tolerance range of 0.01 to 0.06 [46], the cross-sectional dimensions of the column need to be enlarged.

2.5. Quantity and Cost Analysis. The RC components consist of concrete work (measured in a cubic meter), reinforcement work (measured in kilogram), and formwork (measured in square meter). A spreadsheet application was used to support the quantity take-off (QTO) analysis. The quantity of concrete work $\left(Q_{\mathrm{C}}\right)$ was computed as the sum of all $\mathrm{RC}$ beams or columns based on the concrete section area $\left(A_{\mathrm{C}}\right)$ and the length of RC beams or columns $(L)$, as shown in 
equation (1). The number and diameter of reinforcement bars should be designed as the total area closest required area $\left(A_{\mathrm{R}}\right)$. The quantity of reinforcement work $\left(Q_{\mathrm{R}}\right)$ was determined by the rebars number and length $\left(L_{\mathrm{R}}\right)$ and then converted into weight units (meter to kilogram) using the weight to length conversion index $(c)$, as shown in equation (2). The quantity of formwork $\left(Q_{F}\right)$ is the total area of formwork used to cast a beam or column and determined by the casting perimeter length $\left(L_{\mathrm{P}}\right)$ of concrete and the length of RC beams or columns $(L)$, as shown in equation (3):

$$
\begin{gathered}
\text { Concrete Quantity }\left(Q_{\mathrm{C}}\right)=\sum_{i=1}^{n} A_{\mathrm{C} i} \cdot L_{i} \text {, } \\
\text { Reinforcement Quantity }\left(\mathrm{Q}_{\mathrm{R}}\right)=\sum_{i=1}^{n} L_{\mathrm{R} i} \cdot c_{i} \text {, } \\
\text { Formwork Quantity }\left(\mathrm{Q}_{\mathrm{F}}\right)=\sum_{i=1}^{n} L_{\mathrm{P} i} \cdot L_{i} .
\end{gathered}
$$

The unit price (UP) of work is the primary reference for calculating the price of an $\mathrm{RC}$ component of the building structure. The UPs of work are calculated based on the prices and requirements of materials, labor, equipment, and overhead/profit. The UP of works used in this study refers to the results of previous studies [48]. All price uses for cost analysis were measured in Indonesian Rupiah (IDR). The costs of works $\left(C_{\mathrm{W}}\right)$ for all structural components were obtained from the multiplication between the quantity of work $\left(Q_{i}\right)$ and the unit price of work $\left(\mathrm{UP}_{i}\right)$ as follows:

$$
C_{\mathrm{W} i}=\sum_{i=1}^{n} \mathrm{Q}_{i} \times \mathrm{UP}_{i}
$$

The overall form of change for the costs of RC components was analyzed cumulatively by adding up the total cost for RC beams and RC columns. The change patterns of the cost were explained in two aspects. Firstly, the cost patterns were explained based on the composition of the RC cost of works. The cost compositions describe the percentage cost of work to the total cost of components, namely, RC beams and RC columns. Secondly, the cost changes were defined based on the relationship between the total cost (TC) of whole RC components and the potential seismic load in each zone. The TC was determined as the total cost per square meter of the building area from the two RC components reviewed. A linear regression approach was used to describe the total cost (TC) as a function of spectral acceleration $\left(S_{\mathrm{S}}\right)$ from the zones observed for each importance factor $\left(I_{\mathrm{e}}\right)$ as follows:

$$
\mathrm{TC}_{i}=f\left(S_{\mathrm{S}}\right), \quad \text { for } I_{\mathrm{e}}=1.00 ; 1.25 ; 1.50 .
$$

\section{Results and Discussions}

3.1. Changes in the Dimension of RC Beam and Column. Structural analysis of RC beams for all three types of beams begins by setting the initial concrete area of $60,000 \mathrm{~mm}^{2}$, $100,000 \mathrm{~mm}^{2}$, and $50,000 \mathrm{~mm}^{2}$, respectively, for tie beam, floor beam, and roof beam. These dimensions were applied in the reference zone, namely, Zone $10\left(S_{\mathrm{S}}=0.691 \mathrm{~g}\right)$ and importance factor $\left(I_{\mathrm{e}}\right)$ 1.00. The outputs of RC beams dimensions for all variations are shown in Table S1 of Supplementary Material. The results of the analysis and design dimensions of the component indicated that the concrete area $\left(A_{\mathrm{C}}\right)$ was possibly applied in some subsequent zones or building occupancy categories. In this condition, the reinforcement area $\left(A_{\mathrm{R}}\right)$ increases following the increase in seismic loads. The reinforcement ratio (RL) will also increase in line with the reinforcement area $\left(A_{\mathrm{R}}\right)$. At the point of the $\mathrm{RL}$ exceeding the limit, it indicated that $A_{\mathrm{R}}$ is no longer proportional to the $A_{\mathrm{C}}$. It means that the dimension of concrete should be enlarged. An increase in seismic loads due to changes in spectral acceleration $\left(S_{S}\right.$ and $\left.S_{1}\right)$ and building occupancy, as defined by importance factors, directly affects the reinforcement area $\left(A_{\mathrm{R}}\right)$.

The concrete area of the RC columns for a building shows the same pattern in both types of columns, while the area of the column was unaffected on both floors of the building, as shown in Table S2 of Supplementary Material. A significant difference was seen in the reinforcement area for the first-floor column and second-floor column as a consequence of the loads received by the structure. In general, the reinforcement area for first-floor columns can be twice as large as the second-floor column. The dimensions of the concrete column in one zone or building occupancy category for the succeeding zones or categories can still be used as long as the reinforcement ratio (RL) was still within the reference limit. This condition was typical as in the changes in the dimensions of the RC beam.

3.2. The Percentage of RC Cost. The quantity take-off (QTO) analysis was carried out for three cost components of the work, namely, concrete work, reinforcement work, and formwork. The QTO was conducted based on the dimension outputs for concrete and reinforcement elements. Specifically for reinforcement, the output of the area should be converted in the arrangement of the number and diameter of the rebar to be installed in the RC components, as shown in Tables S3 and S4 of the Supplementary Material. The quantity of formwork increases following the change in dimensions of concrete beams and columns. The increase in the quantity of reinforcement is in line with the result of previous studies [41, 49].

The results of the $\mathrm{RC}$ costs were determined based on the quantity and unit price of works, as seen in Tables S5 and S6 of Supplementary Materials. The total cost of RC will change significantly with its quantity, as shown in Tables 2 and 3.

The lowest costs for RC beams appear in Zones 10 to Zone 13 for $I_{\mathrm{e}}=1.00$, while the highest costs occur in buildings in Zone 16 for $I_{\mathrm{e}}=1.50$. For RC columns, the lowest cost appears in buildings in Zone 10 for $I_{\mathrm{e}}=1.00$ and the highest cost occurs in buildings in Zone 16 for $I_{\mathrm{e}}=1.25$. The increasing costs of these two structural components show a slightly different form. The consistency of the increase in costs is relatively more noticeable in $\mathrm{RC}$ beams rather than RC columns. For RC columns, the total cost of work shows a relatively fluctuating pattern of increases and 
TABLE 2: The total cost of RC beam.

\begin{tabular}{|c|c|c|c|c|c|c|c|c|}
\hline \multirow{2}{*}{$I_{\mathrm{e}}$} & \multicolumn{8}{|c|}{ The total cost of RC beam per zone (in thousand IDR) } \\
\hline & 10 & 11 & 12 & 13 & 14 & 15 & 16 & 19 \\
\hline 1 & 443,667 & 443,667 & 443,667 & 443,667 & 464,722 & 464,722 & 481,573 & 481,573 \\
\hline 1.25 & 510,117 & 510,117 & 510,605 & 510,605 & 518,676 & 531,758 & 536,158 & 519,698 \\
\hline 1.5 & 510,117 & 519,413 & 510,605 & 532,039 & 562,936 & 565,603 & 591,096 & 563,636 \\
\hline
\end{tabular}

TABLE 3: The total cost of RC column.

\begin{tabular}{lccccccr}
\hline \multirow{2}{*}{$I_{\mathrm{e}}$} & \multicolumn{7}{c}{ The total cost of RC column per zone (in thousand IDR) } \\
& 10 & 11 & 12 & 13 & 14 & 15 & 16 \\
\hline 1 & 239,491 & 276,536 & 289,161 & 289,161 & 254,387 & 269,389 & 279,471 \\
1.25 & 250,988 & 250,988 & 288,688 & 288,688 & 316,290 & 342,176 & 366,501 \\
1.5 & 265,990 & 311,191 & 323,701 & 323,701 & 312,122 & 353,899 & 344,943 \\
\hline
\end{tabular}

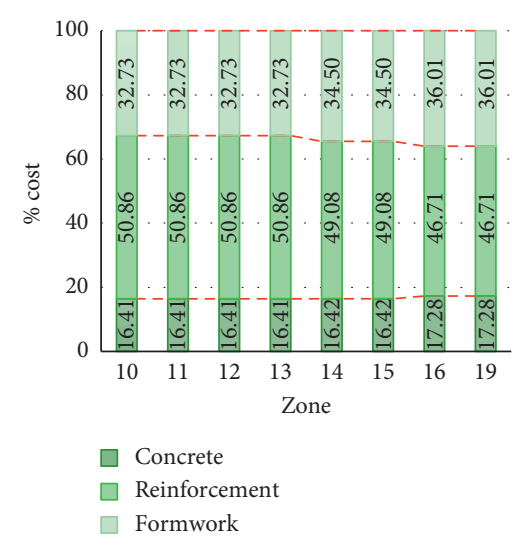

(a)

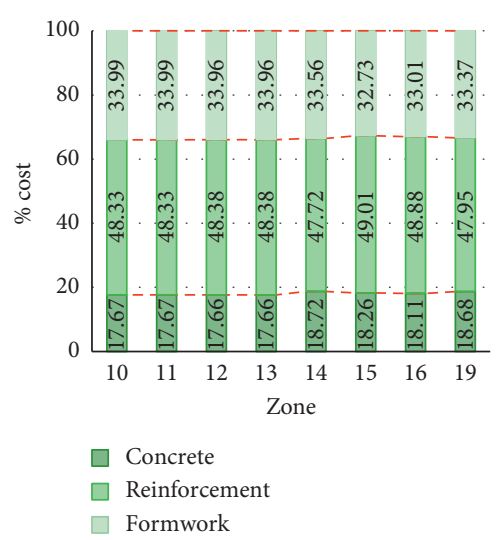

(b)

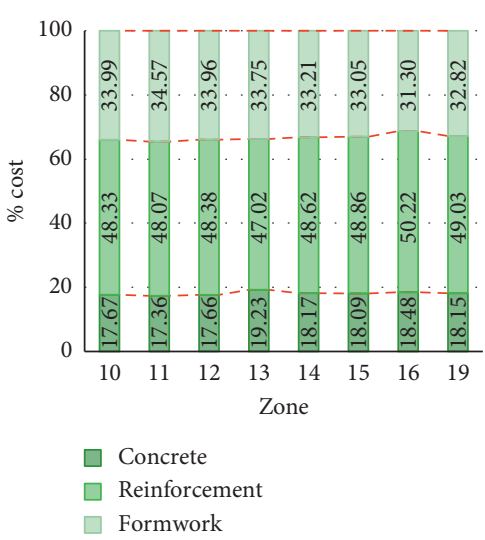

(c)

Figure 3: Percentage cost of works for RC beam: (a) for $I_{\mathrm{e}}=1.00$; (b) for $I_{\mathrm{e}}=1.25$; (c) for $I_{\mathrm{e}}=1.50$.

decreases from one zone to the next, as seen in buildings with $I_{\mathrm{e}}=1.00$. These fluctuations are an indication of changes in the reinforcement ratio to meet the needs of each reinforcement following changes in seismic loads in all zones observed.

The cost of each RC component can be determined according to the composition of the cost of works. Changes in the composition of costs for concrete work, reinforcement work, and the cost of formwork for each RC component are expressed as a percentage. This percentage reflects the proportion of the cost of works to total costs for each structural component. The cost composition of the two RC components is shown in Figures 3 and 4.

The cost composition for reinforced concrete works is dominated by reinforcement costs, both for RC beams and columns, and then followed by formwork and concrete work. This condition also confirms the results of the other studies [42, 43]. Reinforcement work accounts for almost $50 \%$ of the total cost of works.

3.3. The Pattern of Changes in the Total Cost per Square Meter of Building Area. The total cost of the RC components is correlated to the potential seismic load in each zone that is represented by the spectral acceleration parameters, as denoted by $S_{\mathrm{S}}$. The total cost of RC components was simplified based on the building area per square meter. The regression analysis was used to express the relationship between the two variables. Changes in the total costs are shown in Figure 5.

The lowest cost for all RC components was found in Zone 10 (for $S_{\mathrm{S}}=0.691$ and $I_{\mathrm{e}}=1.00$ ) as the basis to determine the percentage of cost changes for subsequent zones. Data representation by the regression equation was adequate according to the indication of the $R^{2}$ values of the three equations above $50 \%$. The increase in the total cost per square meter for buildings designed by using importance factor $\left(I_{\mathrm{e}}\right) 1.00$ has a tendency to be inclined slightly. A different condition was found in buildings designed by using a higher index of importance factors that presented greater slopes as an indication of higher costs increase.

For each seismic zone, the total cost of RC components shows an increase following the increase in the index of importance factors $\left(I_{\mathrm{e}}\right)$. The total cost increases $12.86 \%$ on average, with standard deviations of $4.86 \%$ for the building designed with $I_{\mathrm{e}}=1.00$ to $I_{\mathrm{e}}=1.25$. The total 


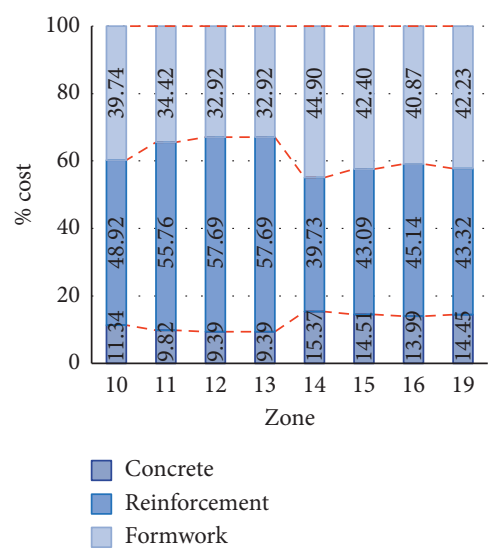

(a)

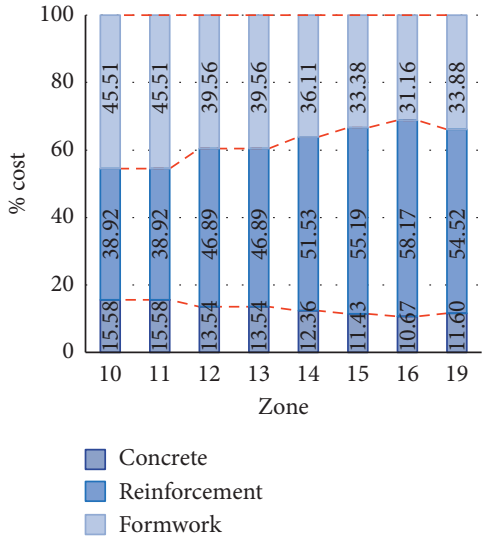

(b)

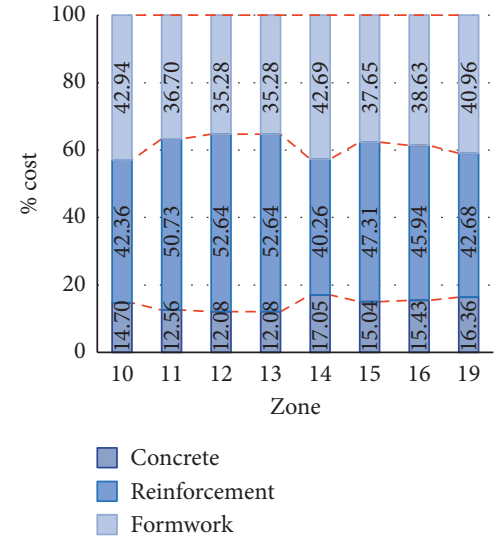

(c)

Figure 4: Percentage cost of works for RC column: (a) for $I_{\mathrm{e}}=1.00$; (b) for $I_{\mathrm{e}}=1.25$; (c) for $I_{\mathrm{e}}=1.50$.

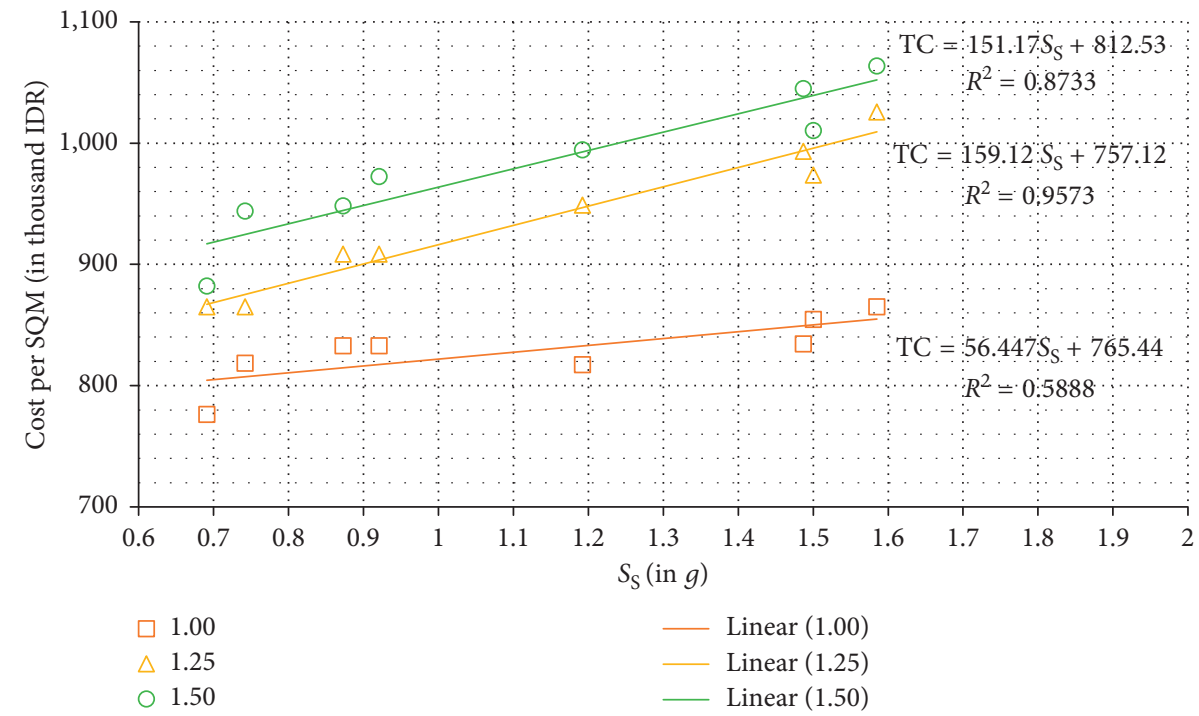

Figure 5: Cost and seismic loads of the combined RC component.

cost of the building designed with $I_{\mathrm{e}}=1.25$ to $I_{\mathrm{e}}=1.50$ increases by $5.00 \%$ on average with standard deviations of $2.21 \%$. These conditions indicate that changes in the occupancy category, as represented in the $I_{\mathrm{e}}$ of building design, will have a significant impact on changes to the building costs.

According to the importance factors, the total cost per square meter in a zone to another tends to be increased by following the regression equations, as shown in Figure 5. The incremental of $S_{\mathrm{S}}$ value for $0.1 \mathrm{~g}$ can result in an increase in costs of $0.68 \%, 1.70 \%$, and $1.54 \%$, respectively, for $I_{\mathrm{e}}=1.00$, $I_{\mathrm{e}}=1.25$, and $I_{\mathrm{e}}=1.50$. These conditions conclude that the total cost of the structure changes significantly following changes in seismic load for the seismic design categories in each zone.

\section{Conclusions}

This paper studied the changes in structural component costs of the RC beam and RC column of a building due to changes in seismic load. The load variations in the structure consider the seismic design categories (as represented in eight seismic zones, in $S_{S}$ ) and the building occupancy categories (as defined by three importance factors, $I_{\mathrm{e}}$ ).

The study indicated that seismic loads are an important factor that must be considered in cost estimation. The cost estimation process should be carried out by considering aspects of variations in seismic loads in a building if it is planned to be built at different locations. This consideration is required to ensure that a building is designed effectively from the aspect of structural resistance to earthquakes, as well as being efficient in terms of its economic aspects. The total cost required for structural components will increase in line with the increase in seismic loads. In sequence, changes in seismic load will have an impact on the structural dimensions, which are then followed by changes in the quantity of work, and in the end affect the increase in costs. The relationship of the total cost described the pattern of changes to the seismic potentials, as expressed in the $S_{\mathrm{S}}$ parameters. Increasing in total costs per square meter for 
incremental in $S_{\mathrm{S}}$ value of $0.1 \mathrm{~g}$ are $0.68 \%$ (for $I_{\mathrm{e}}=1.00$ ), $1.70 \%$ (for $I_{\mathrm{e}}=1.25$ ), and $1.54 \%$ (for $I_{\mathrm{e}}=1.50$ ).

The study also confirmed that variations in building occupancy categories contribute to increased costs in the design of a building. The difference in occupancy categories has consequences for the potential risks for building users when the building is damaged or even collapsed due to exceeding seismic loads. Applying the importance factors as represented in variations in building occupancy shows a significant impact on the increase in total building costs. Furthermore, implementation of this study can be directed at the establishment of cost estimates standard, especially for conceptual cost estimates. For government budget planners, the results of this study can also be a reference in evaluating the budget allocation policy for a typical building planned in a different region.

\section{Data Availability}

The data used to support the findings of this study are included within the supplementary information file.

\section{Conflicts of Interest}

The authors declare that there are no conflicts of interest regarding the publication of this paper.

\section{Acknowledgments}

This research was supported with funding by the PLK grant from Research and Community Services Institute, Universitas Syiah Kuala, with contract no. 73/UN11.2/PP/ PNBP/SP3/2018 of Fiscal Year 2018. The authors express immense gratitude to the Construction Engineering and Management Laboratory, Civil Engineering Department, Universitas Syiah Kuala, for all contributions to this research.

\section{Supplementary Materials}

Table S1: the dimension of RC beams. Table S2: the dimension of RC columns. Table S3: the quantity of work for RC beams. Table S4: the quantity of work for RC columns. Table S5: the cost of RC beams components. Table S6: the cost of RC columns components. (Supplementary Materials)

\section{References}

[1] Q. Jiao, H. Jiang, and Q. Li, "Building earthquake damage analysis using terrestrial laser scanning data," Advances in Civil Engineering, vol. 2019, Article ID 8308104, 12 pages, 2019.

[2] C.-W. Chiou and H.-J. Wang, "Damage to Chinese courtyard houses during the September 21, 1999 Chi-Chi earthquake in Taiwan," Journal of Earthquake Engineering, vol. 15, no. 5, pp. 711-723, 2011.

[3] M. H. Arslan and H. H. Korkmaz, "What is to be learned from damage and failure of reinforced concrete structures during recent earthquakes in Turkey?," Engineering Failure Analysis, vol. 14, no. 1, pp. 1-22, 2007.
[4] E. Wahyuni, "Vulnerability assessment of reinforced concrete building post-earthquake," Procedia Earth and Planetary Science, vol. 14, pp. 76-82, 2015.

[5] E. Irwansyah and S. Hartati, "Assessment of building damage hazard caused by earthquake: integration of FNN and GIS," IERI Procedia, vol. 10, pp. 196-202, 2014.

[6] A. Ghobarah, M. Saatcioglu, and I. Nistor, "The impact of the 26 December 2004 earthquake and tsunami on structures and infrastructure," Engineering Structures, vol. 28, no. 2, pp. 312-326, 2006.

[7] M. Munirwansyah, R. P. Munirwan, M. Sungkar, and Z. Melinda, "The effect of soil-structure interaction on multistorey building resonance and dynamic shear modulus for Pidie Jaya Aceh earthquake," IOP Conference Series: Materials Science and Engineering, vol. 523, p. 12038, 2019.

[8] T. Saidi, T. B. Aulia, B. Setiawan, N. Abdullah, and M. Hasan, "Spectral displacement (SD) of banda aceh's soft soil for seismic vulnerability assessment," MATEC Web of Conferences, vol. 197, p. 10001, 2018.

[9] K. B. Hitoshi and T. Galambos, "Earthquake load for structural reliability," Journal of Structural Engineering, vol. 115, no. 6, pp. 1446-1462, 1989.

[10] J. Takagi and A. Wada, "Recent earthquakes and the need for a new philosophy for earthquake-resistant design," Soil Dynamics and Earthquake Engineering, vol. 119, pp. 499-507, 2019.

[11] M. Affan, M. Syukri, L. Wahyuna, and H. Sofyan, "Spatial statistic analysis of earthquakes in Aceh Province year 19212014: cluster seismicity," Aceh International Journal of Science and Technology, vol. 5, no. 2, pp. 54-62, 2016.

[12] R. Adams, C. Lomnitz, P. Burton, I. Haigh, and P. Willmore, "Informal discussion. Seismic zoning," Proceedings of the Institution of Civil Engineers, vol. 66, no. 4, pp. 819-821, 1979.

[13] M. F. Chacón, J. C. de la Llera, M. A. Hube, J. Marques, and A. Lemnitzer, "Epistemic uncertainty in the seismic response of RC free-plan buildings," Engineering Structures, vol. 141, pp. 687-702, 2017.

[14] P. Kotronis and S. Grange, "Simplified modelling strategies for reinforced concrete structures," European Journal of Environmental and Civil Engineering, vol. 14, no. 6-7, pp. 823-838, 2010.

[15] M. Liu, "Progressive collapse design of seismic steel frames using structural optimization," Journal of Constructional Steel Research, vol. 67, no. 3, pp. 322-332, 2011.

[16] L. Jiang and J. Ya, "Impact of wall configurations on seismic fragility of steel-sheathed cold-formed steel-framed buildings," Advances in Civil Engineering, vol. 2018, Article ID 2528549, 11 pages, 2018.

[17] S. Tesfamariam, J. Madheswaran, and K. Goda, "Displacement-based design of hybrid RC-timber structure: seismic risk assessment," Journal of Structural Engineering, vol. 145, no. 11, Article ID 4019125, 2019.

[18] F. Fabbrocino, I. Farina, and M. Modano, "Loading noise effects on the system identification of composite structures by dynamic tests with," Composites Part B: Engineering, vol. 115, pp. 376-383, 2019.

[19] M. Ghannoum, A. Imtiaz, S. Grange, M. Causse, C. Cornou, and J. Baroth, "Behavior of a RC frame under differential seismic excitation," Journal of Earthquake Engineering, pp. 1-22, 2018.

[20] A. R. Habibi and K. Asadi, "Seismic performance of reinforced concrete moment resisting frames with setback based on Iranian seismic code," International Journal of Civil Engineering, vol. 12, no. 1A, pp. 41-54, 2014. 
[21] O. Arroyo, A. V. Osorio, and M. C. Vargas, "A method to improve the seismic performance of steel moment resisting frames based on eigenfrequency optimization," Advances in Civil Engineering, vol. 2019, Article ID 8385342, 10 pages, 2019.

[22] J. Xiao, Y. Sun, and H. Falkner, "Seismic performance of frame structures with recycled aggregate concrete," Engineering Structures, vol. 28, no. 1, pp. 1-8, 2006.

[23] J. Donaire-Ávila, F. Mollaioli, A. Lucchini, and A. BenaventCliment, "Intensity measures for the seismic response prediction of mid-rise buildings with hysteretic dampers," Engineering Structures, vol. 102, pp. 278-295, 2015.

[24] N. Wongpakdee and S. Leelataviwat, "Influence of column strength and stiffness on the inelastic behavior of strongcolumn-weak-beam frames," Journal of Structural Engineering, vol. 143, no. 9, Article ID 4017124, 2017.

[25] S. R. Uma, "Seismic behavior of beam column joints in reinforced concrete moment resisting frames," Earthquake, vol. 2, no. 7, pp. 1-36, 2015.

[26] A. E. Zaghi, S. Soroushian, A. Itani, E. Manos Maragakis, G. Pekcan, and M. Mehrraoufi, "Impact of column-to-beam strength ratio on the seismic response of steel MRFs," Bulletin of Earthquake Engineering, vol. 13, no. 2, pp. 635-652, 2015.

[27] B. Chang, T. C. Hutchinson, X. Wang, and R. Englekirk, "Experimental seismic performance of beam-column subassemblies using ductile embeds," Journal of Structural Engineering, vol. 139, no. 9, pp. 1555-1566, 2013.

[28] M. B. D. Hueste and J.-W. Bai, "Seismic retrofit of a reinforced concrete flat-slab structure: part I-seismic performance evaluation," Engineering Structures, vol. 29, no. 6, pp. 11651177, 2007.

[29] P. J. Wilkinson and O. Lavan, "Extension of the effective modal seismic design method to generally irregular RC wall structures," Bulletin of Earthquake Engineering, vol. 16, no. 11, pp. 5341-5370, 2018.

[30] P. Heerema, M. Shedid, and W. El-Dakhakhni, "Seismic response analysis of a reinforced concrete block shear wall asymmetric building," Journal of Structural Engineering, vol. 141, no. 7, Article ID 4014178, 2015.

[31] S. Barakat, A. Shanableh, S. Altoubat, and K. Abu-Dagga, "Assessment of seismic structural risk for model buildings in the City of Sharjah, UAE," Jordan Journal of Civil Engineering, vol. 12, no. 1, pp. 125-138, 2018.

[32] A. S. Bhosale, R. Davis, and P. Sarkar, "Vertical irregularity of buildings: regularity index versus seismic risk," ASCE-ASME Journal of Risk and Uncertainty in Engineering Systems, Part A: Civil Engineering, vol. 3, no. 3, Article ID 4017001, 2017.

[33] H. Dilmac, H. Ulutas, H. Tekeli, and F. Demir, "The investigation of seismic performance of existing RC buildings with and without infill walls," Computers and Concrete, vol. 22, no. 5, pp. 439-447, 2018.

[34] H. Tekeli, H. Dilmac, F. Demir, M. Gencoglu, and K. Guler, "Shear stress indicator to predict seismic performance of residential RC buildings," Computers and Concrete, vol. 19, no. 3, pp. 283-291, 2017.

[35] R. K. McGuire, "Probabilistic seismic hazard analysis: early history," Earthquake Engineering and Structural Dynamics, vol. 37, no. 3, pp. 329-338, 2008.

[36] S. Husin, F. Fachrurrazi, M. Rizalihadi, and M. Mubarak, "Implementing fuzzy topsis on project risk variable ranking," Advances in Civil Engineering, vol. 2019, Article ID 9283409, 10 pages, 2019.
[37] R. Jafarzadeh, J. Ingham, and S. Wilkinson, "A seismic retrofit cost database for buildings with a framed structure," Earthquake Spectra, vol. 30, no. 2, pp. 625-637, 2014.

[38] Mahmuddin and Mubarak, "Housing rehabilitation budget due to earthquake disaster by using multiple linear regression models," in Proceedings of the of 9th AIWEST-DR, pp. 52-59, Banda Aceh, Indonesia, October 2014.

[39] M. D. Pandey and J. A. M. van der Weide, "Probability distribution of the seismic damage cost over the life cycle of structures," Structural Safety, vol. 72, pp. 74-83, 2018.

[40] N. Caterino, B. M. Azmoodeh, and G. Manfredi, "Seismic risk mitigation for a portfolio of reinforced concrete frame buildings through optimal allocation of a limited budget," Advances in Civil Engineering, vol. 2018, Article ID 8184756, 18 pages, 2018.

[41] Tripoli, Mubarak, Nurisra, and Mahmuddin, The implementation of unit price of work standard SNI 7394: 2008 for the construction of reinforced concrete beam," IOP Conference Series: Materials Science and Engineering, vol. 352, p. 12027, 2018.

[42] N. E. Lozano-Ramírez and E. E. Muñoz-Díaz, "Seismic and direct costs comparison of conventional and nonconventional structural systems used for an irregular building," Journal of Architectural Engineering, vol. 21, no. 2, Article ID 5015001, 2015.

[43] M. AlHamaydeh, K. Galal, and S. Yehia, "Impact of lateral force-resisting system and design/construction practices on seismic performance and cost of tall buildings in Dubai, UAE," Earthquake Engineering and Engineering Vibration, vol. 12, no. 3, pp. 385-397, 2013.

[44] SNI 1726:2012, The Earthquake Resistance Planning Procedures for the Structure of Buildings and Non-Buildings, National Standardization Board, Jakarta, Indonesia, 2012.

[45] SNI 1727:2013, The Minimum Loads for Building and Other Structures Design, National Standardization Board, Jakarta, Indonesia, 2013.

[46] SNI 2847:2013, The Concrete Structural Requirements for Buildings, National Standardization Board, Jakarta, Indonesia, 2013.

[47] Indonesia spectral design, ," February 2019, http://puskim.pu. go.id/Aplikasi/desain_spektra_indonesia_2011/.

[48] Mubarak, Abdullah, M. Riza, and Y. Hayati, "Changes in the unit price of work for reinforced concrete construction based on building sites," IOP Conference Series: Materials Science and Engineering, vol. 523, p. 12035, 2019.

[49] M. Mubarak, T. Tripoli, and N. Nurisra, "The unit price implication of reinforcement usage in tie beam reinforced concrete construction," Aceh International Journal of Science and Technology, vol. 7, no. 1, pp. 24-31, 2018. 


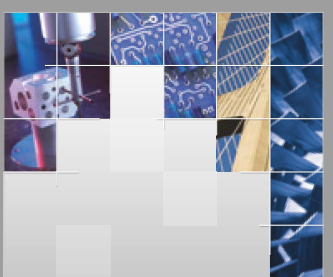

\section{Enfincering}
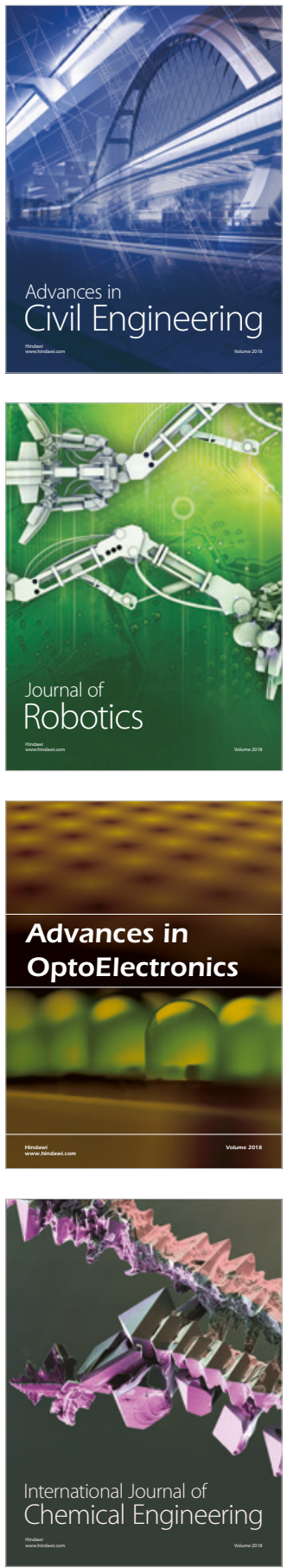

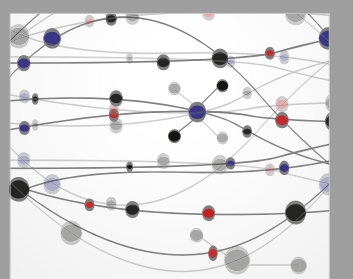

\section{Rotating \\ Machinery}

The Scientific World Journal

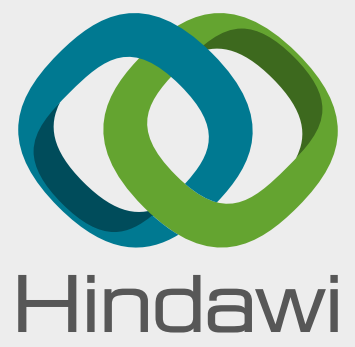

Submit your manuscripts at

www.hindawi.com
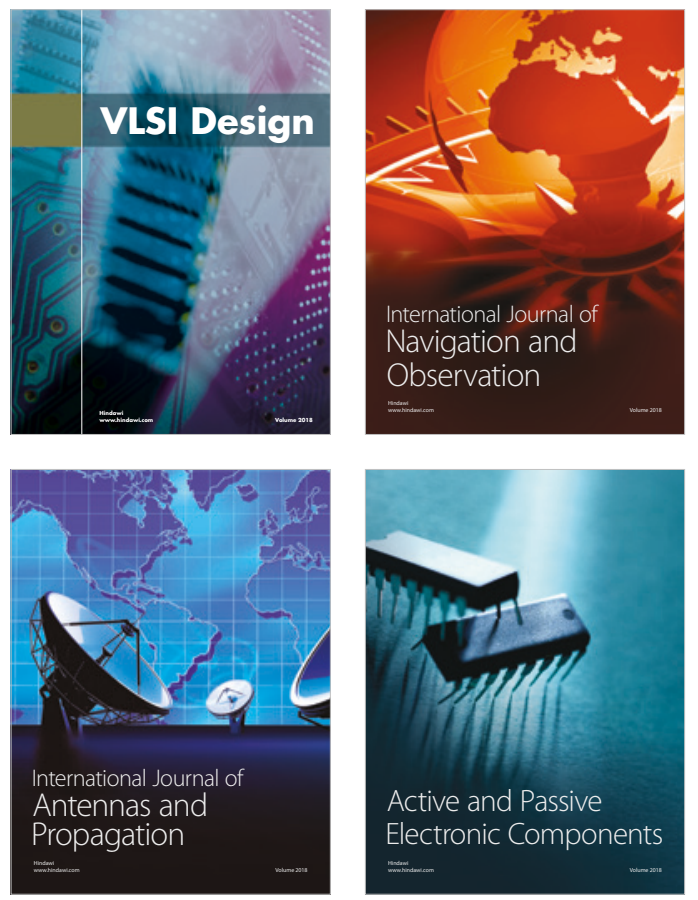
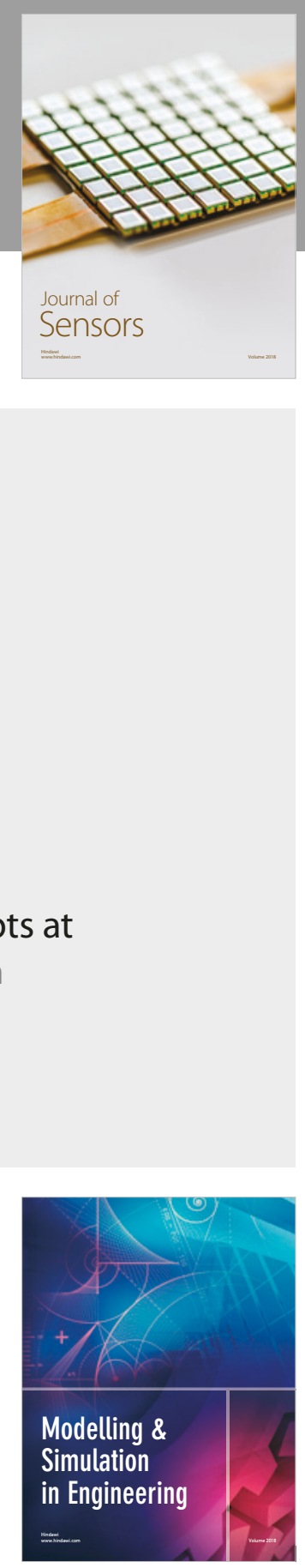

\section{Advances \\ Multimedia}
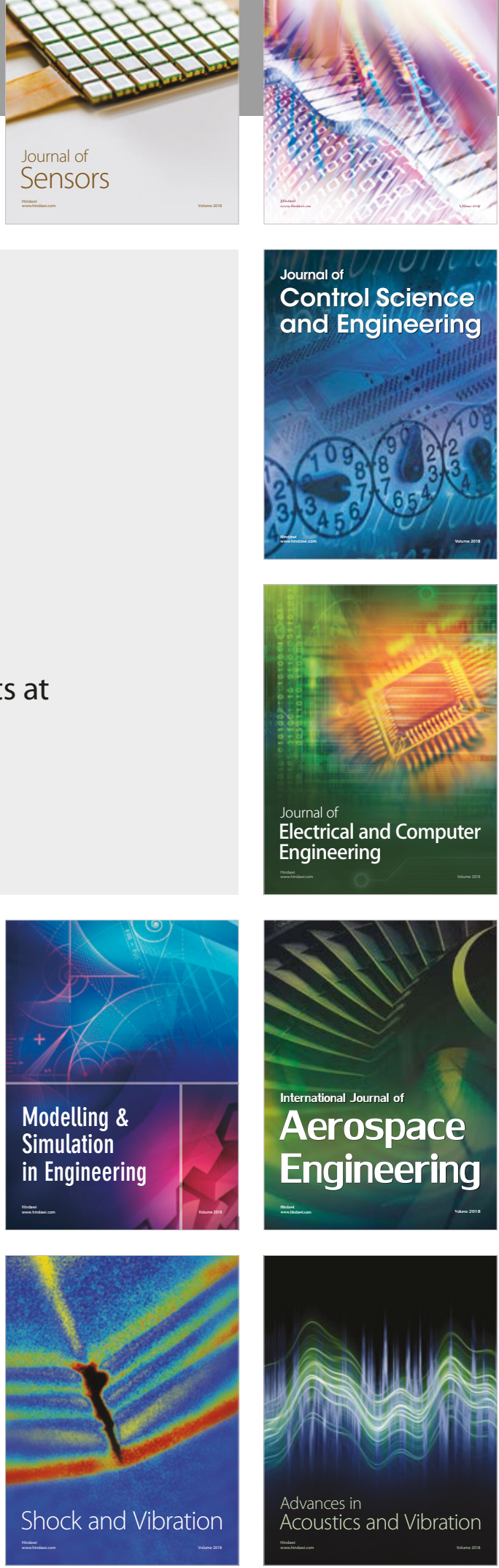